\title{
IMPLEMENTASI PENILAIAN BERBASIS PORTOFOLIO DI PAUD LAISMANEKAT NASIPANAF
}

\author{
Retno Jeki Krisnadina Lopo ${ }^{1}$, Siti Masitoh ${ }^{2}$, Retno Tri Hariastuti ${ }^{3}$ \\ Program Studi Pendidikan Dasar, Pascasarjana, Universitas Negeri Surabaya \\ E-mail: rettnolopo@gmail.com; sitimasitoh@unesa.ac.id; retnotri@unesa.ac.id.
}

APA Citation: Lopo, Retno Jeki Krisnadina., Siti Masitoh., Retno Tri Hariastuti . (2020). Implementasi Penilaian

Berbasis Portofolio di PAUD Laismanekat Nasipanaf k. Jurnal Pelita PAUD, 4(2), 187-196.

doi: https://doi.org/10.33222/pelitapaud.v4i1.970

Diterima:14-05-2020

Disetujui: 22-05-2020

Dipublikasikan: 05-06-2020

\begin{abstract}
Abstrak: Penelitian ini bertujuan untuk mendeskripsikan dan mengevaluasi implementasi/penerapan penilaian berbasis portofolio di PAUD Laismanekat Nasipanaf Kupang.

Berdasarkan hasil analisis data, disimpulkan bahwa dalam penerapan penilaian berbasis portofolio di PAUD Laismanekat Nasipanaf Kupang meliputi empat hal, yaitu (1) Konteks: penilaian yang dilakukan sesuai dengan pedoman penilaian PAUD Permendikbud RI No 146 Tahun 2014, (2) Input: Masukan dalam penelitian ini, adalah latar belakang pendidik, sarana prasarana yang tersedia cukup menunjang, dan peran guru pada penilaian portofolio mendukung, (3) Proses pelaksanaan penilaian berbasis portofolio sesuai dilakukan berdasarkan langkah-langkah penilaian portofolio menurut Supranata dan Hatta, (4) Produk atau hasil penilaian berbasis portofolio yang dilakukan yaitu berupa dokumen semua perkembangan anak yang sudah dikumpulkan selama satu semester yaitu satu bendel map dengan menuliskan nama dari masing-masing anak serta raport anak. Kesimpulan dari keseluruhan evaluasi implementasi penilaian berbasis portofolio sudah cukup baik namun masih diperlukan pembenahan dalam penggunaan pedoman penilaian yang ada.
\end{abstract}

Kata kunci: Penilaian, Portofolio, Anak Usia Dini

Abstract: This study aims to describe and evaluate the implementation / application of portfoliobased assessment in PAUD Laismanekat Nasipanaf Kupang. Based on the results of data analysis, it was concluded that in the application of portfolio-based assessment in PAUD Laismanekat Nasipanaf Kupang includes four things, namely (1) Context: the assessment was conducted in accordance with the guidelines for PAUD Permendikbud RI assessment No. 146 of 2014, (2) Input: Input in research this is the background of educators, facilities provided sufficient support, and the role of teachers in the portfolio assessment support, (3) the implementation process based assessment portfolio choco ai is based on measures of portfolio assessment according Supranata and Hatta, (4) Product or results portfolio-based assessment is carried out in the form of a document of all child development that has been collected during one semester, namely one bundle map by writing the name of each child and the child's report card. The conclusion from the overall evaluation of the implementation of portfolio-based assessments is quite good but improvements are still needed in the use of existing assessment guidelines.

Keywords : Assessment, Portfolios, Early Childhood

(C) 2020 Retno Jeki Krisnadina Lopo ${ }^{1}$, Siti Masitoh² ${ }^{2}$ Retno Tri Hariastuti ${ }^{3}$ Under the license CC BY-SA 4.0

http://jurnal.upmk.ac.id/index.php/pelitapaud 
P ISSN 2548-6284 E ISSN 2615-0360

Vol. 4 No. 2 Juni 2020

PENDAHULUAN

Pada hakikatnya pendidikan merupakan suatu proses membangun peradaban bangsa, dan pendidikan harus berarah pada konsep perubahan, penumbuhkembangan anak-anak bangsa menjadi peribadi yang baik (beriman, bertakwa, berbudi pekerti luhur, memiliki nilai moral), mampu berkomunikasi, bergaul dengan baik, saling menghargai, dan memiliki kematangan emosional (terampil/memiliki kecakapan hidup, dan berbudaya). Tujuan esensial pendidikan adalah demi pengembangan potensi serta kemampuan anak dalam rangka memelihara dan meningkatkan martabat manusia (human dignity). Yaitu, manusia yang memiliki kecerdasan (intelligence, spiritual and emotional) untuk menjalani kehidupannya dengan bertanggung jawab, baik secara pribadi maupun sosial.

Salah satu upaya untuk menciptakan generasi yang unggul dan berkualitas, maka pendidikan harus dilaksanakan sejak usia dini dan berlangsung sepanjang hayat (long life education). Menurut para ahli teori perkembangan sependapat bahwa masa usia dini (early cildhood) merupakan masa dimana anak tumbuh dan berkembang dengan sangat pesat dan pada usia (0-6 tahun) disebut sebagai usia emas (golden age). Di masa usia emas (golden age) ini anak memiliki banyak potensi yang dapat dikembangkan secara optimal, dan untuk mengembangkan potensi anak secara optimal maka anak perlu mendapatkan pendidikan. Pendidikan yang baik akan membuat anak bertumbuh dan berkembang dengan baik pula. Hal ini berarti bahwa pendidikan anak usia dini (PAUD) sangat esensial bagi perkembangan anak selanjutnya.

Pendidikan anak usia dini (PAUD) adalah pendidikan yang paling fundamental karena perkembangan anak di masa selanjutnya akan sangat ditentukan oleh berbagai stimulasi bermakna yang diberikan sejak usia dini. Awal kehidupan anak merupakan masa yang paling tepat dalam memberikan stimulasi atau upaya pengembangan agar anak dapat berkembang secara optimal. Sesuai dengan Undang-Undang Nomor 20 Tahun 2003 tentang Sistem Pendidikan Nasional Bab 1 pasal 1 butir 14 menyatakan bahwa: "Pendidikan Anak Usia Dini merupakan suatu upaya pembinaan yang ditujukan kepada anak sejak lahir sampai dengan usia enam (0-6) tahun yang dilakukan melalui rangsangan pendidikan untuk membantu pertumbuhan dan perkembangan jasmani dan rohani agar anak memiliki kesiapan belajar dalam memasuki pendidikan lebih lanjut". Kedudukan PAUD sebagai bagian dari pendidikan sepanjang hayat dan diwujudkan dalam bentuk keikutsertaan pendidikan yang ditampilkan melalui kegiatan belajar oleh setiap individu.

Pembelajaran di PAUD merupakan serangkaian kegiatan yang memungkinkan terjadinya proses belajar pada anak. Menurut Yus (2011:21), pembelajaran penting bagi pertumbuhan dan perkembangan anak dalam rentang perkembangan hidup seseorang, karena pembelajaran sebagai suatu proses yang harus dirancang, dikembangkan dan dikelola secara kreatif, dinamis, dengan menerapkan pendekatan multi untuk menciptakan suasana dan proses pembelajaran yang kondusif bagi anak. Dalam hal ini, pelaksanaan kegiatan pembelajaran di PAUD hendaknya berlandaskan pada empat pilar pendidikan UNESCO, yaitu: learning to know (melalui media dan penjelasan guru); learning to do (melakukan aktivitas langsung); learning to be (dengan bermain peran); dan learning to live together (berinteraksi dengan anak lain dengan mentaati setiap ketentuan dan peraturan yang berlaku).

Pelaksanaan kegiatan pembelajaran di PAUD merupakan hasil modifikasi komponen-komponen pembelajaran yang terdiri dari tujuan, materi/topik, metode, media, dan penilaian. Komponen tujuan dimodifikasi menjadi kegiatan yang menunjukkan kemampuan (kompetensi), materi/topik menjadi tema dan sub tema kegiatan, metode dan media ditekankan pada media pelaksanaan pembelajaran serta penilaian tetap menjadi komponen penilaian (assessmen dan/atau evaluation). Kelancaran dalam pelaksanaan pembelajaran pada PAUD juga sangat tergantung pada kecakapan dan keterampilan guru/pendidik dalam merancang serta mengelola pembelajaran. Korelasinya dengan kualitas pengelolaan PAUD adalah mutu pembelajaran dan pencapaian hasil yang akan diraih anak. Setiap guru/pendidik berkewajiban melakukan evaluasi dan penilaian terhadap hasil belajar anak untuk mengetahu tingkat pengetahuan, pemahaman dan keterampilan anak dalam pembelajaran. Hal ini telah disebutkan dalam Permendikbud Nomor 137 Tahun 2014 tentang Standar Pendidik dan Tenaga Kependidikan bahwa: "Pendidik anak usia dini 
P ISSN 2548-6284 E ISSN 2615-0360

Vol. 4 No. 2 Juni 2020

merupakan tenaga profesional yang bertugas merencanakan, melaksanakan pembelajaran, dan menilai hasil pembelajaran, serta melakukan pembimbingan, pelatihan, pengasuhan dan perlindungan".

Pembelajaran di PAUD harus memperhatikan standar-standar penyelenggaraan pendidikan anak usia dini yang telah ditetapkan oleh pemerintah dalam Peraturan Menteri Pendidian dan Kebudayaan RI Nomor 137 Tahun 2014 tentang Standar Nasional Pendidikan Anak Usia Dini terdiri atas delapan standar yaitu standar tingkat pencapaian perkembangan anak, standar isi, standar proses, standar penilaian, standar pendidikan dan tenaga kependidikan, standar sarana dan prasarana, standar pengelolaan, dan standar pembiayaan.

Salah satu standar yang harus dilakukan oleh guru pendidikan anak usia dini adalah standar penilaian. Penilaian berfungsi memberi informasi tentang proses kegiatan pembelajaran yang telah dilalui anak, bagaimana kegiatan tersebut telah dilakukan dan kegiatan apa lagi yang mungkin akan dilakukan. Artinya bahwa, penilaian merupakan komponen yang tidak kalah pentingnya dibanding dengan komponen lainnya, seperti langkah kegiatan, tema, sub tema kegiatan, media dan pelaksanaan pembelajaran.

Melihat begitu pentingnya penilaian dalam kegiatan belajar anak usia dini maka, Yus (2011:3) menegaskan bahwa guru/pendidik harus benarbenar mencermati komponen penilaian seperti halnya komponen kegiatan lainnya. Selain harus memahami konsep penilaian, guru harus dapat menetapkan kapan waktu yang tepat serta cara dan alat apa yang paling sesuai digunakan untuk menilai kegiatan pelaksanaan pembelajaran.

Namun demikian, penilaian yang dilakukan terhadap anak usia dini sangat berbeda dengan penilaian terhadap anak SD atau tingkat pendidikan lainnya. Tidak hanya karena alasan bahwa anak usia dini belum mampu menulis dan membaca dengan lancar, tetapi juga karena pada tahap perkembangan anak tersebut membutuhkan berbagai cara penilaian yang tepat. Hal tersebut berimplikasi pada suatu pemahaman bahwa penilaian haruslah menjadi lebih variatif, kreatif, dan produktif untuk membentuk kompetensikompetensi yang diharapkan muncul pada anak. Cara memberikan berbagai kegiatan yang menuntut aktifitas belajar dan bermakna serta menerapkan apa yang dipelajari dalam konteks nyata melalui authentic assessment (penilaian autentik). Penilaian autentik adalah penilaian proses dan hasil belajar untuk mengukur tingkat pencapaian kompetensti sikap (spiritual dan sosial), pengetahuan dan keterampilan yang dilakukan secara berkesinambungan (Permendikbud Nomor 146 Tahun 2014). Penilaian tidak hanya mengukur apa yang diketahui oleh anak, tetapi lebih menekankan mengukur apa yang dapat dilakukan oleh anak.

Kegiatan pelaksanaan penilaian dalam pembelajaran konstruktivisme sama sekali tidak bergantung pada bentuk penilaian yang menggunakan kertas dan pensil (misalnya: tes tulis, baca dan hitung) ataupun tes objektif. Teknik penilaian yang dapat digunakan untuk penilaian kompetensi sikap, pengetahuan dan keterampilan pada PAUD adalah: pengamatan atau observasi, percakapan, penugasan, unjuk kerja, hasil karya, pencatatan anekdot, dan portofolio (Permendikbud Nomor 146 Tahun 2014 tentang Kurikulum 2013 Pendidikan Anak Usia Dini).

Salah satu teknik penilaian yang digunakan di PAUD adalah dengan menggunakan teknik portofolio. Dengan berkembangnya dunia pendidikan dan tuntutan global, maka adanya inovasi pendidikan yang melibatkan penggunaan teknologi dalam pendidikan yaitu salah satunya adalah dengan penilaian e-portfolio (penilaian menggunakan portofolio elektronik). Dalam jurnal pengembangan e-portfolio sebagai instrumen penilaian siswa di SMK Negeri 2 Lamongan, Nurhayati \& Sumbawati (2014) menyimpulkan bahwa penugasan e-portfolio yang dikembangkan memenuhi syarat valid dan reliabel, serta efektif untuk digunakan sebagai instrumen penilaian. Namun, mengingat penelitian yang dilakukan di PAUD Laismanekat Nasipanaf Kupang memiliki keterbatasan dalam penggunaan teknologi sehingga masih menggunakan penilaian portofolio manual.

Penilaian portofolio mendasarkan pada teori belajar konstruktivistik oleh Piaget, Vygotsky \& Brunner (dalam Sujiono, 2009: 116) yang mengasumsikan bahwa anak selain unik, mereka adalah active learners, bahkan a scientist. Mereka memiliki kepekaan, sensitif, they construct their own knowledge by themselves. Berdasarkan pemikiran ini, pencapaian perkembangan belajar anak tidaklah patut untuk dibandingkan dengan perkembangan kelompoknya (norm reference assessment) namun 
P ISSN 2548-6284 E ISSN 2615-0360

Vol. 4 No. 2 Juni 2020

perkembangan anak selayaknya dibandingkan dengan kemampuan perkembangan sebelumnya atau kriteria pencapaian kompetensi. Dalam kaitan ini, portofolio digunakan untuk mengetahui perkembangan hasil belajar anak yang bertumpu pada perbedaan individual selama proses pembelajaran berlangsung.

Portofolio merupakan penilaian berkelanjutan yang didasarkan pada kumpulan catatan informasi guru selama anak mengikuti proses pembelajaran dan hasil karya yang dikerjakan oleh anak saat pembelajaran. Selanjutnya, di analisis dalam bentuk deskripsi, baik berupa gambar atau tulisan sederhana yang dibuat anak. Kumpulan hasil catatan informasi guru dan hasil karya anak selama satu minggu/bulan/semester, dianalisis/dikaji untuk mengetahui tingkat perkembangan kemampuan anak berdasarkan kompetensi/indikator yang telah ditetapkan dan untuk memperoleh kesimpulan tentang gambaran akhir perkembangan anak. Penilaian portofolio ini akan dapat merekam setiap kemajuan yang diperoleh anak dari waktu ke waktu.

Jamaris (2006: 64) mengungkapkan bahwa penilaian portofolio merupakan alat penilaian yang cocok untuk anak usia dini karena dapat menilai hasil belajar anak dari waktu ke waktu. Portofolio berbentuk berbagai sajian-sajian dan unjuk kerja atau bukti nyata dari hasil belajar anak. Hal ini juga diungkapkan oleh Patmonodewo (2003: 146), bahwa penilaian portofolio adalah berdasarkan pada hasil berbagai pekerjaan anak, catatan guru, dan evaluasi diri yang dilakukan anak. Guru mengumpulkan hasil perkembangan anak misalnya dalam bentuk catatan anekdot, observasi, percakapan, penugasan, unjuk kerja maupun hasil karya anak dalam beberapa minggu/bulan/tahun berupa gambar, tugas melipat, menggunting dan sebagainya. Selanjutnya, dalam Permendikbud Nomor 146 Tahun 2014 tentang Kurikulum 2013 Pendidikan Anak Usia Dini Salinan Lampiran V Pedoman Penilaian, portofolio merupakan kumpulan atau rekam jejak berbagai hasil kegiatan anak secara berkesinambungan atau catatan pendidik tentang berbagai aspek pertumbuhan dan perkembangan anak sebagai salah satu bahan untuk menilai kompetensi sikap, pengetahuan, dan keterampilan.

Portofolio bersifat dinamik dan merupakan kumpulan hasil kerja dari anak serta catatan perkembangan dari guru guna membantu penilaian terhadap anak. Hasil karya anak dan catatan perkembangan dari guru dalam kegiatan pembelajaran tidak hanya dikumpulkan kemudian dibagikan pada akhir semester atau akhir tahun pembelajaran. Tetapi hasil karya anak dan catatan perkembangan dari guru dianalisis secara kolaboratif dengan melibatkan guru, anak, dan orang tua. Sehingga dengan kerjasama tersebut guru dan orang tua dapat mengetahui kelebihan, kelemahan, minat dan bakat anak. Maka guru bersama-sama dengan orang tua dapat memberikan bantuan belajar yang tepat untuk anak tersebut sehingga diperoleh hasil belajar yang optimal.

Berdasarkan uraian tersebut, maka penilaian portofolio mempermudah guru dalam mengetahui berbagai potensi anak, karakter, kelebihan, dan kekurangan yang dimiliki oleh anak. Selain itu, portofolio juga membantu guru dalam penilaian proses belajar, terutama dalam memperbaiki strategi dan metode pembelajaran yang telah digunakan yang mungkin dirasa kurang efektif.

Menurut Barton \& Collins (dalam Yamin, 2008:206), semua bahan portofolio atau evidence dapat diklasifikasikan menjadi empat macam, yaitu: (1) hasil karya peserta didik (artifacts), yaitu hasil karya peserta didik yang dihasilkan di kelas, (2) Reproduksi (reproductions) yaitu hasil kerja peserta didik yang dikerjakan di luar kelas, (3) Pengesahan (attestations) yaitu pernyataan dan hasil pengamatan yang dilakukan oleh guru atau pihak lainnya tentang peserta didik, (4) Produksi (production) yaitu hasil kerja peserta didik yang dipersiapkan khusus untuk portofolio.

Berkenaan dengan prosedur penerapan dan implementasi penilaian berbasis portofolio, Surapranata \& Hatta (2004: 99) mengutarakan sebelas langkah tahapan utama yang perlu diperhatikan oleh guru, antara lain: (1) menentukan tujuan portofolio, (2) menentukan isi portofolio, (3) menentukan kriteria penilaian, (4) menentukan format penilaian, (5) melakukan pengamatan dan penilaian, (6) penentuan koleksi (collection), (7) menyeleksi evidence (selection), (8) refleksi (reflection), (9) pertemuan, (10) sumber dan pengorganisasian, dan (11) hubungan (connection). Sebagaimana dikemukakan terdahulu, bahwa setiap kemajuan yang diperoleh anak dari waktu ke waktu dapat dideteksi diantaranya dapat menganalisis atau mengkaji kumpulan hasil karya anak dan berbagai 
P ISSN 2548-6284 E ISSN 2615-0360

Vol. 4 No. 2 Juni 2020

catatan perkembangan anak dari guru selama satu periode tertentu untuk mengetahui tingkat perkembangan kemampuan anak berdasarkan kompetensi/indikator yang telah ditetapkan dan untuk memperoleh gambaran akhir perkembangan anak melalui penilaian berbasis portofolio. Penilaian portofolio menerapkan prinsip proses dan hasil belajar secara seimbang. Penilaian portofolio mengikuti setiap aspek perkembangan anak, bagaimana cara belajar anak, bagaimana motivasi belajar, sikap, minat, kebiasaan, dan pada akhirnya bagaimana hasil belajar yang diperoleh anak. Berdasarkan hal tersebut, penilaian berbasis portofolio lebih memberikan kesempatan tumbuh dan berkembang secara optimal sesuai dengan potensi yang dimilikinya serta sesuai dengan tahaptahap perkembangan anak.

Dari penjelasan di atas, tampak jelas pentingnya implementasi penilaian berbasis portofolio sebagai teknik penilaian pada jenjang PAUD. Hal ini juga diungkapkan oleh Suyadi (2016) dalam penelitiannya yang menyimpulkan bahwa teknik asesmen yang paling banyak digunakan adalah teknik portofolio dikarenakan sifatnya yang sederhana, mudah dilaksanakan, namun mampu memberikan gambaran umum perkembangan pada diri anak. Tetapi, kendala yang sering dihadapi oleh guru PAUD adalah kurangnya pemahaman tentang penerapan penilaian berbasis portofolio. Hal ini diketahui dari hasil wawancara awal yang dilakukan peneliti dengan guru-guru PAUD Laismanekat Nasipanaf Kecamatan Taebenu Kabupaten Kupang.

Kenyataan lainnya adalah bahwa penilaian berbasis portofolio yang sudah dilakukan oleh guru/pendidik, belum melibatkan anak dan orang tua dalam melakukan penilaian portofolio anak maka penilaian tersebut terkadang dilakukan oleh guru di luar jam pembelajaran. Dengan kerjasama antara guru dan orang tua sangat dibutuhkan dalam rangka untuk mengetahui potensi anak sehingga dapat mengembangkan potensi tersebut secara optimal. Keterlibatan anak dalam penilaian juga sangat penting. Hal ini diperkuat dengan penelitian Silva \& Craveiro (2014) bahwa keterlibatan anak dalam penilaian mereka sendiri adalah keuntungan untuk mengembangkan proses mental penataan diri dan mendorong anak untuk menerapkan, menganalisis, mensintesis, dan mengevaluasi pencapaian yang mereka peroleh saat proses pembelajaran.

Berdasarkan uraikan tersebut, penulis tertarik untuk mengadakan penelitian dan mengkaji lebih lanjut tentang "Implementasi Penilaian Berbasis Portofolio di PAUD Laismanekat Nasipanaf Kecamatan Taebenu Kabupaten Kupang", dengan harapan dapat mendeskripsikan dan menggali lebih dalam bagaimana implementasi penilaian berbasis portofolio di PAUD Laismanekat Nasipanaf Kupang. Maka tujuan yang hendak dicapai dalam penelitian ini adalah sebagai berikut: 1). Evaluasi Konteks meliputi: Mendeskripsikankesesuaian penilaian portofolio dengan Permendikbud RI No 146 Tahun 2014; 2). Evaluasi Input meliputi: a). Mendeskripsikan latar belakang pendidik PAUD; b). Mendeskripsikan kesesuaian peran guru pada penilaian portofolio; dan c). Mendeskripsikan kesesuaian ketersediaan prasarana dan sarana dalam kegiatan penilaian dengan kebutuhan pada saat kegiatan penilaian berlangsung; 3). Evaluasi Proses meliputi: Mendeskripsikan pelaksanaan penilaian berbasis portofolio yang meliputi: Perkembagan apa yang menjadi sasaran penialain belajar anak, langkah-langkah penialain berbasis portofolio dan bentuk laporan penilain berbasis portofolio yang digunakan dalam penilaian berbasis portofolio di PAUD Laismanekat Nasipanaf Kupang; dan 4). Evaluasi Produk meliputi: Mendeskripsikan pencapaian hasil penilaian berbasis portofolio di PAUD Laismanekat Nasipanaf Kupang.

\section{METODE PENELITIAN}

Jenis penelitian ini adalah penelitian evaluasi dengan analisis data menggunakan analisis deskriptif kualitatif. Penelitian ini menggunakan model penelitian evaluasi CIPP (context evaluation, input evaluation, process evaluation, dan product evaluation) Evaluation Model. Penelitian ini dilakukan di PAUD Laismanekat Nasipanaf Kupang. Sumber data yang digunakan peneliti adalah kepala sekolah PAUD Laismanekat, pendidik kelas A dan kelas B, dan orang tua anak. Teknik pengumpulan data berupa observasi, wawancara dan dokumentasi. 
P ISSN 2548-6284 E ISSN 2615-0360

Vol. 4 No. 2 Juni 2020

\section{HASIL DAN PEMBAHASAN}

\section{Evaluasi Konteks (Context Evaluation)}

Evaluasi konteks merupakan penggambaran dan spesifikasi tentang lingkungan program, kebutuhan yang belum dipenuhi, karakteristik populasi dan sampel dari individu yang dilayani dan tujuan program. Evaluasi kontek membantu merencanakan keputusan, menentukan kebutuhan yang akan dicapai oleh program dan merumuskan tujuan program.

Evaluasi konteks merupakan dasar dari evaluasi yang bertujuan menyediakan alas an-alasan dalam penentuan tujuan (Stufflebeam \& Shienfield, 1985) karena upaya yang dilakukan evaluator dalam evaluasi konteks ini adalah memberikan gambaran dan rincian terhadap lingkungan, kebutuhan serta tujuan. Evaluasi konteks mencakup analisis masalah yang berkaitan dengan lingkungan program atau kondisi obyektif yang harus dilaksanakan. Berisi tentang analisis kekuatan dan kelemahan obyek tertentu.

Stufflebeam \& Shienfield (1985: 128) menyebutkan, tujuan evaluasi konteks yang utama adalah untuk mengetahui kekuatan dan kelemahan yang dimiliki evaluan. Dengan mengetahui kekuatan dan kelemahan ini, evaluator akan dapat memberikan arah perbaikan yang diperlukan.

Orientasi utama dari evaluasi konteks adalah mengidentifikasi latar belakang perlunya mengadakan perubahan atau munculnya program dari beberapa subjek yang terlibat dalam pengambilan keputusan (Mulyatiningsih, 2011: 127). Komponen context dalam penelitian ini adalah kesesuaian penilaian portofolio dengan pedoman penilaian dalam Permendikbud RI No 146 Tahun 2014.

Pedoman penilaian meliputi acuan dalam pelaksanaan penilaian proses dan hasil belajar sesuai dengan Kurikulum 2013 Pendidikan anak usia dini. Perencanaan program dilakukan oleh pendidik yang mencakup tujuan, isi, criteria dan langkah-langkah penilaian berbasis portofolio yang dilaksanakan secara rinci sesuai kebutuhan pendidik.

Pedoman penilaian anak usia dini dalam Permendikbud RI No 146 Tahun 2014 memuat tentang berbagai macam teknik dan isntrumen penilaian. Dengan demikian instrument penilaian yang digunakan dalam penelitian ini adalah instrument portofolio yang sesuai dengan pedoman
Retno Jeki Krisnadina Lopo', Siti Masitoh², Retno Tri Hariastuti ${ }^{3}$

penilaian dalam Permendikbud RI No 146 Tahun 2014

\section{Evaluasi Masukan (Input Evaluation)}

Evaluasi masukan membantu mengatur keputusan, menentukan sumber-sumber yang ada, alternative apa yang diambil, apa rencana dan strategi untuk mencapai tujuan, bagaiman prosedur kerja untuk mencapainya. Informasi yang terkumpul pada saat tahap penilaian hendaknya digunakan untuk menentukan sumber dan strategi di dalam keterbatasan dan hambatan yang ada.

Menurut Widoyoko (2011), evaluasi masukan membantu mengatur keputusan, menentukan sumber-sumber yang ada, alternative apa yang diambil, apa rencana dan strategi untuk mencapai tujuan, dan bagaimana prosedur kerja untuk mencapainya. Komponen evaluasi masukan meliputi: 1) Sumber daya manusia, 2) Sarana dan peralatan mendukung, 3) Dana atau anggaran, 4) berbagai prosedur dan aturan yang diperlukan. Komponen input dalam penelitian ini adalah latar belakang pendidik, peran guru dalam penilaian berbasis portofolio, serta sarana dan prasarana.

Berdasar dari standar pendidik dalam Permendikbud RI No 137 Tahun 2014, maka latar belakang pendidik di PAUD Laismanekat Nasipanaf Kupang yang berupa kompetensi kepribadian; (menyayangi anak, sabar dan santun dalam berperilaku, jujur serta bertanggung jawab), kompetensi professional; (memahami tumbuh kembang anak), kompetensi padagogik; (menyusun rencana kegiatan, melaksanakan serta mengevaluasi pembelajaran) dan komptensi sosial; (menyesuaikan diri, mentaati aturan lembaga serta dapat berkomunikasi secara efektif) dapat disimpulkan sudah cukup sesuai. Ketersediaan tenaga pendidik yang ada sudah cukup memadai untuk melaksanakan proses kegiatan belajar mengajar serta penilaian di PAUD Laismanekat Nasipanaf Kupang.

Dalam penilaian portofolio guru berperan penting agar penilaian adil, transparan dan objektif, dan mudah dimengerti oleh semua pihak, maka guru harus memastikan dengan benar criteria yang akan digunakan dalam penilaian portofolio baik yang kan digunakan untuk kelompok maupun untuk anak secara individu.

Kemampuan anak di kelas sangat bervariasi dari yang kurang mampu sampai ke yang sangat mampu. Untuk itu, pendidik harus membuat criteria 
P ISSN 2548-6284 E ISSN 2615-0360

Vol. 4 No. 2 Juni 2020

yang mencakup rentang kemampuan yang jelas mulai dari kemampuan yanh kurang sampai kemampuan yang tinggi. Seperti yang sudah dijelaskan oleh para pendidik di PAUD Laismanekat Nasipanaf bahwa criteria yang mereka gunakan adalah 1) memberikan nilai degan bintang berdasarkan perkembangan anak, misalnya bintang satu untuk anak yang belum bisa sama sekali mewarnai, bintang dua untuk anak yang sudah bisa mewarnai namun masih berserakan dan seterusnya nilai 2) memberikan penilaian dalam bentuk angka antara 70-100 dan,3) memberikan penilaian dengan keterangan penilaian Belum Berkembang (BB), Mulai Berkembang (MB), Berkembang Sesuai Harapan (BSH) dan Berkembang Sangat Baik (BSB).

Dalam pengembangan penilaian portofolio, pendidik biasanya melakukan observasi kemajuan anak dan dibandingkan dengan komptensi sikap, pengetahuan dan juga keterampilan yang terdapat dalam kurikulum. Hal ini terlihat dari peran para pendidik di PAUD Lismanekat Nasipanaf Kupang pasa saat penilaian yaitu menentukan apa saja isi portofolio yang digunakan, criteria yang akan digunakan dalam penilaian portofoli, menentukan format penilaian, dan juga para pendidik kadang mengalami kendala pada saat penilaian namun para pendidik dapat mengatasi kendala-kendala tersebut dengan berbagai solusi yang ada.

Sarana dan prasarana yang terdapat di PAUD Laismanekat Nasipanaf yang meliputi gedung yang memiliki ruang untuk proses kegiatan belajar mengajar, diantaranya; ruang kelas untuk masingmasing kelompok usia, kamar mandi, ruang kepala sekolah, alat peraga edukatif (APE), alat permainan out door, sebagai penunjang dalam pelaksanaan kegiatan pembelajaran untuk anak usia dini sudah cukup memadai dengan acuan standar sarana dan prasarana dalam Permendikbud RI No 137 Tahun 2014.

\section{Evaluasi Proses (Process Evaluation)}

Evaluasi yang dirancang dan diaplikasikan dalam praktek implementasi kegiatan disebut evaluasi proses. Untuk melihat apakah pelaksanaan program sudah sesuai dengan strategi yang telah dilaksanakan tersebut, maka perlu diadakan evaluasi. Evaluasi tersebut dinamakan evaluasi proses. Evaluasi proses termasuk mengidentifikasi permasalahan prosedur pada pelaksanaan kejadian dan aktifitas.
Setiap perubahan-perubahan yang terjadi pada aktifitas dimonitor secara jujur dan cermat. Pencatatan aktifitas harian penting dilakukan karena berguna pada pengambilan keputusan untuk menentukan tindal lanjut penyempurnaan dan menentukan kekuatan dan kelemahan program. Stufflebeam \& Shienfield (1985: 175) juga menyatakan bahwa evaluasi proses merupakan pengecekan yang berkelanjutan atas implementasi perencanaan.

Tujuan evaluasi proses yaitu untuk mengidentifikasi atau memprediksi dalam proses pelaksanaan, seperti cacat dalam disain prosedur atau implementasinya (Badrujaman, 2009). Selanjutnnya dijelaskan pula bahwa evaluasi proses juga bertujuan untuk menyediakan informasi sebagai dasar meemperbaiki program, serta untuk mencatat, dan menilai prosedur kegiatan dan peristiwa.Selain itu, tujuan utama evaluasi proses adalah sebagai berikut; (1) mengetahui kelemahan selama pelaksanaan termasuk hal-hal yang baik untuk dipertahankan; (2) memperoleh informasi mengenai keputusan yang ditetapkan, dan (3) memelihara catatan-catatan lapangan mengenai halhal penting saat implementasi dilaksanakan.

Berdasarkan pedoman penilaian pada Permendikbud RI No 146, teknik penilaian yang digunakan para pendidik PAUD laismanekat nasipanaf yaitu instrument penilaian portofolio. Penilaian berbasis portofolio yang dilakukan di PAUD Laismanekat Nasipanaf cukup sesuai dengan pedoman penilaian dilihat dari perencanaan program penilaian antara lain, sasaran dari penilaian hasil belajar anak mencakup semua aspek perkembangan anak yaitu (fisik motorik, bahasa, kognitif, nilai moral dan agama, sosial-emosional dan seni), langkah-langkah penilaian portofolio, bentul laporan penilaian portofolio serta cara melaporkan hasil penilaian berbasis portofolio.

\section{Evaluasi Produk/Hasil (Product Evaluation)}

Evaluasi produk merupakan penilaian yang dilakukan untuk mengukur keberhasilan dalam pencapaian yang dilakukan untuk mengukur keberhasilan dalam mencapai tujuan yang telah ditetapkan. Dari hasil evaluasi proses diharapkan dapat membantu guru untuk membuat keputusan yang berkenan dengan kelanjutan, akhir maupun modifikasi program, karena data yang dihasilkan akan sangat menentukan apakah program 
P ISSN 2548-6284 E ISSN 2615-0360

Vol. 4 No. 2 Juni 2020

diteruskan, dimodifikasi, atau dihentikan

(Widoyoko, 2011: 181).

Evaluasi produk merupakan kumpulan deskripsi dan "judgement outcomes" dalam hubungannya dengan konteks, input dan proses, kemudian diinterprestasikan harga dan jasa yang diberikan (Stufflebeam \& Shienfield, 1985). Evaluasi produk adalah evaluasi mengukur keberhasilan pencapaian tujuan. Evaluasi ini merupakan catatan pencapaian hasil dan keputusan-keputusan untuk perbaikan dan aktualisasi. Aktivitas evaluasi produk adalah mengukur dan menafsirkan hasil yang telah dicapai. Pengukuran dikembangkan dan diadministrasikan hasil yang telah dicapai. Pengukuran dikembangkan dan diadministrasikan secara cermat dan teliti. Keakuratan analisis akan menjadi bahan penarikan kesimpulan dan pengajuan saran sesuai standar kelayakan. Secara garis besar, kegiatan evaluasi produk meliputi kegiatan penetapan tujuan operasional program, criteria-kriteria pengukuran yang telah dicapai, membandingkannya antara kenyataan lapangan dengan rumusan tujuan, dan menyusun penafsiran secara rasional.

Analisis produk ini diperlukan pembanding antara tujuan yang ditetapkan dalam rancangan dengan hasil program yang dicapai. Hasil yang dinilai dalam pembahasan ini adalah penilaian berbasis portofolio yang dilakukan para pendidik di PAUD Laismanekat Nasipanaf Kupang yang didapat dari data wawancara dan observasi yang ditelusuri kaitannya dengan tujuan-tujuan yang sudah ditetapkan. Selanjutnya dilakukan analisis kualitatif tentang hasil yang diperoleh dan didapatkan hasil bahwa evaluasi penilaian berbasis portofolio yang dilakukan para pendidik cukup bagus meskipun belum optimal. Kepala Sekolah dan para pendidik PAUD Laismanekat Nasipanaf mengadakan pertemuan (rapat) dengan para orang tua setiap akhir bulan dan juga akhir semester untuk membahas seluruh perkembangan belajar anak dan factor-faktor yang dialami para pendidik dalam melakukan penialain berbasis portofolio.

Hasil penilaian berbasis portofolio terlihat antara lain para pendidik menilai setiap perkembangan anak berdasarkan enam aspek perkembangan anak dan hasil penilaian tersebut dikumpulkan dalam bentuk dokumen yaitu satu bendel map yang berisi juga dengan hasil karya anak pada saat mengikuti kegiatan belajar serta respon orang tua terhadap penilaian berbasis portofolio sangat positif, orang tua dilibatkan dalam penilaian tersebut sehingga mereka memiliki kepuasan terhadap perkembangan anaknya dan merasa ikut dilibatkan dalam membimbing belajar anak di rumah. Disamping itu, sebagaian besar orang tua cukup aktif yaitu inisiatif sendiri untuk berkonsultasi dengan para pendidik mengenai perkembangan anaknya ketika mengantarkan anaknya ke sekolah.

\section{SIMPULAN}

Evaluasi Konteks adalah Kesesuaian penilaian portofolio dengan Permendikbud RI No 146 Tahun 2014, yang meliputi pedomana penilaian dengan teknik dan instrument berbasis portofolio dengan penilaian dapat merangkum berbagai hasil kegiatan anak dan catatan pendidik tentang berbagai aspek pertumbuhan dan perkembangan anak sesuai dengan Permendikbud RI No 146 Tahun 2014.

Evaluasi Input meliputi: Latar belakang pendidik PAUD, Peran guru pada penilaian berbasis portofolio; Kesesuaian ketersediaan sarana dan prasarana

Evaluasi Proses adalah Proses pelaksanaan penilaian berbasis portofolio pada saat penilaian di PAUD Laismanekat Nasipanaf Kupang yang meliputi sasaran penilaian hasil belajar anak, langkah-langkah penilaian berbasis portofolio, bentuk laporan penilaian portofolio, cara melaporkan hasil penilaian portofolio, secara keseluruhan telah dilakukan dan berjalan dengan cukup baik.

Evaluasi Produk merupakan Pencapaian hasil penilaian berbasis portofolio di PAUD Laismanekat Nasipanaf Kupang. Produk atau hasil yang berupa penilaian berbasis portofolio terlihat ketika kepala sekolah dan para pendidik PAUD Laismanekat Nasipanaf melakukan evaluasi dengan mengadakan pertemuan (rapat) dengan para orang tua setiap akhir bulan dan juga akhir semester untuk membahas seluruh perkembangan belajar anak dan factor-faktor yang dialami para pendidik dalam melakukan penialain berbasis portofolio, serta respon orang tua terhadap penilaian berbasis portofolio sangat positif, orang tua dilibatkan dalam penilaian tersebut sehingga mereka memiliki kepuasan terhadap perkembangan anaknya dan merasa ikut dilibatkan dalam membimbing belajar anak di rumah. 
P ISSN 2548-6284 E ISSN 2615-0360

Vol. 4 No. 2 Juni 2020

\section{DAFTAR PUSTAKA}

Arifin, Zainal. (2017). Evaluasi Pembelejaran Prinsip, Teknik dan Prosedur. Bandung: Rosda.

Badrujaman, Aip. (2009). Diktat Teori dan praktek evaluasi program bimbingan konseling. Jakarta.

Creswell, John W. (2014). Research Design Pendekatan Kualitaif, Kuantitatif, dan Mixed.Yogyakarta: Pustaka Pelajar.

Dewi, V. P., Poerwanti, Jenny IS., \& Sutijan. (2018). Penerapan Penilaian Portfolio dalam Asesmen Perkembangan Motorik Halus Anak diTK Segugus Arjuna Kecamatan Jatipurno.Universitas Sebelas Maret.

Fadlillah, Muhammad. (2016). Desain Pembelajaran PAUD. Jogjakarta: Ar-Ruzz Media.

Gede, Wartawan P. (20180. Effect Of Using Portfolio Assessment To Improve Scientific Attitude Of Students Learning Physics In High School.SHS Web of Conferences GC-Tale.

Gelfer, J.I., Xu, Yaoying., \& Perkins, Peggy. G. (2004). Developing Portofoliosto Evaluate Teacher Performance in Early Childhood Education”.Early Childhood Education Journal, 32(2). Nevada: Businnes Media, Inc.

Gustina, Rahani. (2018). Implementation Of Portfolio Assessment In Primary Schools(TesisMaster tidak dipublikasikan), Education Program Teacher Elementary School. Jurusan Ilmu, FKIP Universitas Jambi.

Jamaris, Martini. (2006). Perkembangan dan Pengembangan Anak Usia Taman KanakKanak.Jakarta: Grasindo.

Kementerian Pendidikan Dan Kebudayaan. (2017). Peraturan Menteri Pendidikan DanKebudayaan Republik Indonesia Nomor 137 Tahun 2014 Standar Nasional Pendidikan Anak Usia Dini.

Kementerian Pendidikan Dan Kebudayaan. (2017). Peraturan Menteri Pendidikan DanKebudayaan Republik Indonesia Nomor 146 Tahun 2014 Tentang Kurikulum 2013 Pendidikan Anak Usia Dini.

Knauf, Helen. (2017). Making An Impression: Portfolios As Instruments Of Impression Management For Teachers In Early Childhood Education And Care Centres.Early Childhood Educ J . Doi: 10. 1007/S10643-016-0791-0.
Retno Jeki Krisnadina Lopo', Siti Masitoh², Retno Tri Hariastuti ${ }^{3}$

Kusaeri. (2014). Acuan \& Teknik Penilaian Proses \& Hasil Belajar Kurikulum 2013. Yogyakarta: ArRuzz Media.

Miles, Matthew B dan Huberman, A. Michael. (2014). Analisis Data Kualitatif. Buku SumberTentang Metode-Metode Baru. Jakarta: UI Press.

Moleong, Lexi J. (2013). Metode Penelitian Kualitatif. Edisi Revisi. Bandung: PT RemajaRosdakarya.

Muna, Izza. A. (2017). Jurnal Kependidikan Dasar Islam Berbasis Sains.Ponorogo: Ibriez, 2 (1).

Mulyatiningsih, E. (2011). Metode penelitian terapan bidang pendidikan. Yogyakarta: Alfabeta.

Nazir, M. (2003). Metode penelitian. Jakarta: Ghalia Indonesia.

Nurhayati, F.R., \& Sumbawati, M. S. (2014). Pengembangan E-Portfolio Sebagai Instrumen Penilaian di SMK Negeri 2 Lamongan. Jurnal Pendidikan Teknik Elektro. 03 (01), 253-259.

Patmonodewo, Soemiarti. (2003). Pendidikan Anak Prasekolah. Jakarta: Pusbuk Depdiknas dan Rineka Cipta.

Program Pascasarjana Universitas Negeri Surabaya. (2015). Pedoman Penulisan Tesis Dan Disertasi. Surabaya: Program Pascasarjana Universitas Negeri Surabaya.

Setiyani, Nanik. (2014). Analisis Pelaksanaan Penilaian Portofolio Motorik Halus Anak Usia 4-6 Tahun Oleh Guru Tk Se-Kecamatan Kratek (Tesis master tidak dipublikasikan). Bantul Yogyakarta.

Silva, B. \& Craveiro, C. (2014). O Portefolio Como Estrategia De Avaliacoa Das Aprendizagens $\mathrm{Na}$ Educacao De Infancia: Consideracoes Sobre A Sua Pratica. Electronic Journal. 29 p.033-053. Portugal.

Stufflebeam, D.L \& Shinkfield, A.J. (1985). Avaluation Theory, Models \& Applications. Amerika: JosseyBass.

Sudaryono. (2018). Metodologi Penelitian. Depok: Rajawali Pers.

Sudjana, Nana. \& Ibrahim. (2014). Penelitian Dan Pinilaian Pendidikan. Bandung: Sinar Baru Algensindo.

Sugiyono. (2011). Metode Penelitian Kuantitatif, Kualitatif dan $R \& D$. Bandung: Alfabeta.

Sujiono, Yuliana Nurani. (2009). Konsep Dasar Pendidikan Anak Usia Dini. Jakarta: Indeks. 
Vol. 4 No. 2 Juni 2020

Sukmadinata, Nana. S. (2011). Metode Penelitian Pendidikan. Bandung: Rosdakarya.

Sumardi. Maudyla, Clara V. (2016). Implementasi Model Penilaian Portofolio Dalam Pembelajaran Matematika Berbasis Lesson Study.Prosiding Seminar Matematika dan Pendidikan Matematika. FKIP UNS.

Surapranata, Sumarna. \& Hatta. Muhammad. (2004). Penilaian Portofolio ImplementasiKurikulum 2004. Bandung: Rosda.

Susanto, Ahmad. (2017). Pendidikan Anak Usia Dini (Konsep Dan Teori). Jakarta: Bumi Aksara.

Suyadi. (2016). Perencanaan dan Asesmen Perkembangan Anak Usia Dini. Jurnal lmiahTumbuh Kembang Anak Usia Dini. 1 (1). Universitas Islam Negeri Sunan Kalijaga.

Widoyoko, Eko. P. (2011). Evaluasi Program Pembelajaran. Yogyakarta: Pustaka Pelajar.

Tanwey, Ratumanan T., \& Theresia L. Edisi 3. (2011). Penilaian Hasil Belajar Pada Tingkat Satuan Pendidikan. Yogyakarta: Pensil Komunika.

Yamin, Martinis. (2008). Desain Pembelajaran Berbasis Tingkat Satuan Pendidikan. Jakarta: Gaung Persada Press.

Yus, Anita. (2011). Penilaian Perkembangan Belajar Anak Taman Kanak-Kanak. Jakarta: Kencana.

Zahro, F.I. (2015). Penilaian Dalam Pembelajaran Anak Usia Dini.Tunas Siliwangi. 1(1) 